\title{
Postharvest Longevity of Cut-flower Gerbera. I. Response to Selection for Vase Life Components
}

\author{
Heidi C. Wernett ${ }^{1}$ and Thomas J. Sheehan ${ }^{2}$ \\ Department of Environmental Horticulture, University of Florida, Gainesville, FL 32611
}

Gary J. Wilfret ${ }^{3}$

Gulf Coast Research and Education Center, Institute of Food and Agricultural Sciences, University of Florida, 5007 60th Street East, Bradenton, FL 34203

Francis J. Marousky ${ }^{4}$

College of Agriculture, Sultan Qaboose University, Al-khod, Sultante of Oman

Paul M. Lyrene ${ }^{5}$

Department of Horticultural Sciences, University of Florida, Gainesville, FL 32611

David A. Knauft ${ }^{6}$

Department of Crop Science, North Carolina State University, Raleigh, NC 27695

Additional index words. 'Appleblossom', topcross, diallel, premature senescence

\begin{abstract}
A broad source of Gerbera $\times$ hybrida Hort. germplasm was evaluated for vase life. Senescence mode, i.e., bending or folding of stems or wilting of ligulae was also recorded for flowers evaluated. Intensive selection was practiced to improve vase life. About $10 \%$ of the plants from a sample population were selected for having flowers with high vase life. Progeny means for vase life resulting from a topcross between these plants and 'Appleblossom' were used to select five plants (about $1.5 \%$ of the sample population) whose flowers had high vase life. A diallel cross using these five plants as parents resulted in a progeny population with an increase in mean vase life of 3.4 days compared to mean vase life for the initial sample population. Increases in vase life means for days to bending, folding, and wilting were $0.3,3.5$, and 1.2 days, respectively. Plants with flowers which senesced due to wilting had the longest mean vase life before and after breeding. Changes in proportion of senescence modes were observed; bending decreased, folding and wilting increased. Frequencies of bending, folding, and wilting were compared to vase life means for 10 progenies. Proportion of bending generally decreased as vase life increased.
\end{abstract}

Gerbera Xhybrida Hort. is a popular cut flower. Developed from hybrids of interspecific crosses between G. jamesonii Bolus and $G$. viridifolia Sch. and possibly other species. It is a commercially important member of the Compositae. The distinctive inflorescence, generally measuring $8-14 \mathrm{~cm}$ in diameter, has strapshaped, ray floret ligulae that are white or shades of yellow, orange, or red, surrounding a yellow or black colored center of disc florets. This inflorescence is supported by a long, leafless, and upright scape.

A critical aspect of cut flower postharvest quality is longevity. Researchers have investigated and discussed postharvest longevity in cut flowers, including gerbera, and concluded that it is not the length of lasting quality in itself that is the aim of postharvest longevity but the satisfaction of the consumer (Buys, 1978). Vase life is often used as an indicator of postharvest longevity in cut flowers, and is determined by the number of days from harvest until flower senescence, whether or not senescence is considered premature.

Received for publication 13 Jan. 1995. Accepted for publication 21 Sept. 1995. Florida Agricultural Experiment Station journal series no. R-03796. Based on part of a dissertation accepted for a $\mathrm{PhD}$ at the Univ. of Florida. The cost of publishing this paper was defrayed in part by the payment of page charges. Under postal regulations, this paper therefore must be hereby marked advertisement solely to indicate this fact.

${ }^{1}$ Former graduate student.

${ }^{2}$ Professor emeritus.

${ }^{3}$ Professor (plant geneticist). To whom reprint requests should be addressed.

${ }^{4}$ Former dean (deceased).

${ }^{5}$ Professor.

${ }^{6}$ Professor and department head.
Similar to bent neck in cut roses (Burdett, 1970), knicking (Buys, 1978; Wilberg, 1973), folding (De Jong, 1978a), neck droop (Zieslin et al., 1978), or stem break (Meeteren, 1978a) are terms used to describe the sudden bending of the stem in cut gerberas. This description of premature senescence contrasts with normal senescence. In gerbera, normal senescence is identified as wilting, which is the condition that occurs when the ligulae of an inflorescence on an upright stem have visibly lost their turgidity (De Jong, 1978a).

Postharvest longevity of gerbera has been extended using postharvest treatments (Abdel-Kader and Rogers, 1986; Accati, 1989; Amariutei et al., 1986; Kohl, 1968; Marousky and Woltz, 1975; Meeteren, 1978a; Nowak, 1981; Nowak and Plich, 1981; Waters, 1964) but the extent to which these treatments can improve vase life may be limited by the plant genome.

Improving postharvest longevity in gerbera cut flowers by breeding and selection was considered possible for many years. Smith and Nelson (1967) noted differences in vase life among gerbera cut flowers, and they suggested selection and breeding could minimize this variation. Kohl (1968) proposed selecting cultivars with an increased ability for water uptake and cultivars having structural stem strength are requisite for maintaining the popularity of gerbera as a cut flower. Wilberg (1973) observed differences in the frequency of stem bending among gerbera cultivars and noted the need to breed stems that remain upright. Meeteren (1978b) observed that increased ion leakage in ligulae of gerbera cut flowers depended on the cultivar. Meeteren (1981) suggested pressure potential of ligulae from recently harvested flowers might be a good indicator for vase life and a possible selection criterion in breeding programs to improve postharvest 
longevity in gerberas. Amariutei et al. (1986) reported consistent differences in vase life between two gerberas. 'Symphonie' lasted 2 days longer than 'Richard' either when treated with pulsing agents or when untreated. Heritability of vase life has been estimated by several researchers (Harding et al., 1981, 1987; Serini and De Leo, 1978; Tesi, 1978).

De Jong and Garretsen (1985) analyzed combining ability for postharvest longevity in gerberas using a diallel mating scheme with twelve parents. Three characteristics were examined: vase life (days to wilting or folding); percent folding; and stem curvature. General combining ability was significant for each characteristic. Several conclusions were made: 1) folding results in shorter vase life than wilting; 2) higher curvature may increase the incidence of folding, thereby resulting in shorter vase life; 3) no relationship exists between curvature and percent late folding; and 4) late folding is more difficult to select against than early folding. For the characteristics percent early fold and days to wilt, $67 \%$ and $78 \%$, respectively, of the variation between progeny means was attributed to parents selected. Large intraplant variation for both days to wilt and percent folding was concluded to be the major obstacle in breeding to improve postharvest longevity.

The objective of this research was to undertake a series of studies to evaluate the potential of genetically improving postharvest longevity in gerbera by using plants selected from a broad based source of germplasm, which was phenotypically variable for inflorescence and stem traits. Specifically, objectives of this study were to determine changes in vase life and frequency of senescence patterns due to selection and mating. If gerbera cultivars with superior postharvest longevity are to be developed, then it is necessary to identify characteristics that are suitable for selection and breeding. A determination of narrow sense and broad sense heritability of vase life of the progeny will be presented in the second paper of this series. The role of stem strength as a component of postharvest longevity will be discussed in a future paper.

\section{Materials and Methods}

Plant material. Germplasm was collected from several sources. Eighteen tissue cultured genotypes were European cultivars or selections from a commercial breeding program in the United States (Table 1). Seven seed populations were obtained from five seed companies. In addition, J. Harding (Dept. of Environmental Horticulture, Univ. of California, Davis, Calif.) provided another seed source from his breeding program. J. Harding's seed mixture (Davis population) was the result of eight generations of breeding, but selection for vase life had been discontinued after the fifth generation (Table 2).

Plant material varied in flower color and morphology. The term flower will be used to describe a composite inflorescence sub-

Table 1. Tissue cultured cultivars used in postharvest longevity studies of gerbera.

\begin{tabular}{lccc}
\hline \hline Field \# & Cultivar & Field \# & Cultivar \\
\hline $84-1$ & Amethyst & $84-10$ & SI-1 \\
$84-2$ & Peach & $84-11$ & P15-14-0 \\
$84-3$ & Seashell & $84-12$ & SC300 \\
$84-4$ & Appleblossom & $84-13$ & SC400-8 \\
$84-5$ & Raspberry & $84-14$ & 35 C404-OX \\
$84-6$ & Aztec & $84-15$ & P18-5 \\
$84-7$ & Mandarin & $84-16$ & SB-24 \\
$84-8$ & (Polish line) & $84-17$ & SC205-X \\
$84-9$ & Tropic Lady & $84-18$ & SC 501 \\
\hline
\end{tabular}

Table 2. Seed populations used in postharvest longevity studies of gerbera.

\begin{tabular}{lcc}
\hline \hline Field \# & Population description & Seed source \\
\hline $83-1$ & Davis Population & Univ. of California Davis \\
$83-2^{z}$ & Ahms' F-1 Strain & Herbst Seed Co. (U.S.) \\
$83-3$ & Mardigras F-1 Strain & Ball Seed Co. (U.S.) \\
$83-4$ & Duplex Mixture & Ball Seed Co. (U.S.) \\
$83-5$ & Jongenelen Strain & Ball Seed Co. (U.S.) \\
$83-6$ & Florist Strain Mix & Park Seed Co. (U.S.) \\
$83-7$ & Ramona Mixture & Sluis \& Groot Corp. (Holland) \\
$83-8$ & No. 4 F-1 Mix & Clause Seed Co. (France)
\end{tabular}

${ }^{\mathrm{z}}$ Poor germination, no plants survived.

tended by a stem. Plants grown from four seed populations (Jongenelen, Florists Strain, Ramona, and no. 4 F-1) resembled Dutch cultivars that have flowers with broad ligulae and thick fleshy stems. These populations represented a wide spectrum of flower color. The Duplex mixture was comprised largely of pinkish hues with spindly stems and narrow ligulae. The Mardigras F-1 Strain included doubles and crested inflorescence types and the single, daisy-type form, which were mostly of deep red hues with narrow ligulae. The Davis population mainly exhibited large flowers with narrow ligulae and represented a wide spectrum of flower color. Flowers from these latter two populations had stems of medium thickness.

Selection and mating. Initially 953 plants were grown. Plants which did not flower during a 6 week period before vase life evaluation (5 May-12 June 1984) were discarded. Concurrently, plants were screened for inflorescence type and stem length. Plants were discarded if they did not produce single, daisy-type inflorescences or stem length of $45 \mathrm{~cm}$ or greater when one to two rows of disc florets were open. The remaining plants were then referred to as the parental generation. After the evaluation period, plants that produced fewer than three flowers were also discarded. The residual parental generation included 325 plants. Plant means were determined from data collected on the first three flowers evaluated per plant. Thirty-one plants (about $10 \%$ of the residual parental generation) with longest mean vase life ( $x \geq 11.3$ days) and lowest coefficient of variation $(\leq 25.0)$ were selected. To maintain genetic diversity, selection included plants from each seed population.

A top-cross mating scheme was used as a screening method to determine which of these 31 parents had the longest vase life. 'Appleblossom' was used as the male donor in the top cross mating scheme because of its excellent vase life rating and low intraplant variation. Twenty-eight plants per cross were grown to produce the top-cross generation. Plants that did not flower from 12 Mar.-15 May 1985 were discarded. After the evaluation period, plants that produced less than three flowers were also discarded. Plant means were determined from data collected on three flowers per plant. Progeny means were determined for each cross from individual plant means. Finally, five plants (about $1.5 \%$ of the residual parental generation) with longest progeny mean vase life were selected. To maintain genetic diversity, selection included plants from four seed populations.

A $5 \times 5$ diallel cross was performed using these five parents. Twenty-eight plants per cross were grown to produce the diallel generation. Plants that did not flower during a flowering period before vase life evaluation (23 May-6 Aug. 1987) were discarded. Plant means were determined from data collected on one to three flowers per plant. The diallel crossing was used to create a selected generation to examine for response to selection.

Vase life evaluation. Flowers with one to two rows of disc 
florets open were harvested every evening. Stems were then uniformly cut $30 \mathrm{~cm}$ long. Flowers were randomly placed into sterilized glass bottles with one flower per bottle. Each bottle contained $100 \mathrm{ml}$ of deionized water, buffered to $\mathrm{pH}-3.0$ to 3.4 with a citrate-phosphate buffer. The depth of water in each bottle was $4 \mathrm{~cm}$. Every other day, we replaced the bottles and water solution until senescence occurred. Evaluations were conducted in a temperature controlled room (20-21C) with $24 \mathrm{~h}$ /day lighting provided by overhead fluorescent lamps. Light intensity was 10 $15 \mu \mathrm{mol} \cdot \mathrm{m}^{-2} \cdot \mathrm{s}^{-1}$ at flower height. Relative humidity was about $70 \%$. These conditions were patterned after experiments conducted by De Jong (1978a, 1978b) and Harding et al. (1981).

Flower senescence was classified into three modes based on the visual condition of the stem: 1) Bending; the stem gradually, but irreversibly, loses turgidity, resulting in an arc. If allowed to persist, the stem eventually appears folded 2) Folding; the stem suddenly bends, resulting in an irreversible sharp angle 3) Wilting; the stem remains rigid and upright until the ligulae wilt. Vase life was measured by the number of days to flower senescence: vase life $=$ senescence date - harvest date.

Production. Plants were grown in 12.5-cm (1.4-liter) standard plastic pots on raised benches in a clear glass greenhouse at the Univ. of Florida in Gainesville. Minimum night temperature was maintained at about 18C. Day temperature was set at 30C. A fan and pad cooling system was used to control the temperature. Shade cloth of $25 \%$ density covered the greenhouse since light intensity generally exceeds $1600 \mu \mathrm{mol} \cdot \mathrm{m}^{-2} \cdot \mathrm{s}^{-1}$ per day in Florida.

Mature plants were irrigated, using drip irrigation, at two intervals per day; morning and late afternoon. Late afternoon irrigation (about 2-3 h before harvest) was made to reduce the possibility of preharvest water stress.

\section{Results}

Selection and mating. Vase life means for 31 parents selected for top-cross mating with 'Appleblossom' ranged from 11.3 to 16.0 days. Coefficients of variation ranged from 0.0 to 24.7. Progeny means resulting from the top-cross ranged from 6.1 to 10.7 days (Table 3 ). The parental mean and top-cross mean of the five parents selected for diallel mating is given in Table 4. Progeny means resulting from diallel mating ranged from 8.7 to 14.3 days (Table 5). Following selection and breeding, the population mean for vase life increased by 3.4 days.

Senescence patterns. Distribution of vase life data on individual flowers from the parental and diallel generations was compared and, in addition to a shift in the mean from 7.8 days to 11.2 days, the frequency of vase life did not appear normally distributed in both generations. Before selection there was a higher frequency of flowers with low rather than high vase life. After selection and mating, this trend was reversed (Fig. 1).

We also compared distribution of vase life data by senescence mode. In both generations, vase life frequency appeared to be normally distributed. After selection and mating, vase life means for days to bending, folding, and wilting increased. The largest increase in mean vase life occurred in flowers that folded, which was 3.5 days. Smaller increases were observed in flowers that bent and wilted, which was 0.3 and 1.2 days, respectively (Figs. 2-4).

After selection and mating, the proportion of flowers in the diallel generation that senesced due to bending, folding, and wilting differed from that observed in the parental generation (Fig. 5). The incidence of bending reduced by an average of $41 \%$. Folding and wilting increased by an average of $23 \%$ and $18 \%$, respectively. In both generations, the frequency of wilting exceeded that of folding.
Table 3. Vase life (in days) for 31 parents from a population of gerbera.

\begin{tabular}{|c|c|c|c|}
\hline \multirow[b]{2}{*}{ Parent } & \multicolumn{2}{|c|}{ Parental generation } & \multirow{2}{*}{$\begin{array}{l}\text { Top-cross generation } \\
\text { progeny mean }\end{array}$} \\
\hline & mean $^{2}$ & $\mathrm{CV}$ & \\
\hline $83-1-6$ & 13.0 & 20.4 & 6.8 \\
\hline $83-1-13$ & 11.3 & 5.1 & 6.8 \\
\hline $83-1-26$ & 16.0 & 16.6 & 7.7 \\
\hline $83-1-32$ & 12.3 & 4.7 & 8.2 \\
\hline $83-1-61$ & 12.3 & 9.4 & 6.8 \\
\hline $83-1-64$ & 15.0 & 17.6 & 7.9 \\
\hline $83-1-74$ & 13.7 & 23.5 & 6.9 \\
\hline $83-1-77^{y}$ & 15.3 & 24.7 & 8.6 \\
\hline $83-3-4$ & 11.7 & 9.9 & 7.5 \\
\hline $83-3-34$ & 13.3 & 11.5 & 7.2 \\
\hline $83-3-38$ & 15.7 & 7.4 & 8.7 \\
\hline $83-3-47$ & 13.0 & 20.4 & 7.4 \\
\hline $83-3-77$ & 13.0 & 7.7 & 6.4 \\
\hline $83-3-96$ & 13.3 & 11.5 & 7.4 \\
\hline $83-4-4$ & 11.7 & 5.0 & 6.1 \\
\hline $83-4-17$ & 12.3 & 20.4 & 6.3 \\
\hline $83-4-38$ & 11.3 & 5.1 & 7.8 \\
\hline $83-4-69^{y}$ & 12.0 & 8.3 & 9.6 \\
\hline $83-5-33$ & 14.0 & 7.1 & 7.6 \\
\hline $83-5-39$ & 16.0 & 22.5 & 10.4 \\
\hline $83-5-109^{y}$ & 13.0 & 21.7 & 8.9 \\
\hline $83-6-42$ & 14.3 & 17.6 & 7.9 \\
\hline $83-7-4^{y}$ & 12.3 & 18.7 & 10.2 \\
\hline $83-7-6$ & 13.7 & 16.9 & 7.8 \\
\hline $83-7-10^{y}$ & 16.0 & 0.0 & 10.7 \\
\hline $83-7-14$ & 12.7 & 18.2 & 6.6 \\
\hline $83-7-18$ & 14.3 & 10.7 & 6.9 \\
\hline $83-7-26$ & 12.3 & 18.7 & 9.4 \\
\hline $83-7-29$ & 16.0 & 0.0 & 9.4 \\
\hline $83-7-47$ & 12.7 & 4.6 & 8.6 \\
\hline $83-8-7$ & 11.3 & 5.1 & 7.6 \\
\hline
\end{tabular}

${ }^{\mathrm{z}}$ Based on three flowers per plant.

yParents selected for diallel mating.

Table 4. Vase life (in days) for five gerbera parents.

\begin{tabular}{lcc}
\hline \hline Parent & $\begin{array}{c}\text { Parental generation } \\
\text { mean }\end{array}$ & $\begin{array}{c}\text { Top-cross generation } \\
\text { progeny mean }\end{array}$ \\
\hline $83-1-77$ & 15.3 & 8.6 \\
$83-4-69$ & 12.0 & 9.6 \\
$83-5-109$ & 13.0 & 8.9 \\
$83-7-4$ & 12.3 & 10.2 \\
$83-7-10$ & 16.0 & 10.7 \\
\hline
\end{tabular}

The frequency of bending, folding, and wilting in progeny of the diallel generation was compared to progeny means for vase life (Fig. 6). Among 10 progenies, the proportion of bending generally decreased as vase life increased. With the exception of one cross, about $50 \%$ of the flowers wilted in progenies with vase life of 11 days or greater. About $25 \%$ of the flowers wilted in progenies with vase life of less than 11 days. The proportion of folding did not appear related to progeny means for vase life.

An analysis of variance was made on the total number of vase life observations in the diallel generation (Table 6). Differences in vase life of flowers among crosses and among plants within crosses were highly significant. Data was partitioned to perform separate analyses of variance on vase life observations according to senescence mode; days to bending, days to folding, and days to wilting. 
Table 5 . A $5 \times 5$ diallel. Vase life data from gerbera diallel crosses (reciprocals pooled).

\begin{tabular}{lc}
\hline \hline Cross & $\begin{array}{c}\text { Diallel generation } \\
\text { progeny mean (days) }\end{array}$ \\
\hline $83-1-77 \times 83-4-69$ & 10.3 \\
$83-1-77 \times 83-5-109$ & 8.7 \\
$83-1-77 \times 83-7-4$ & 11.8 \\
$83-1-77 \times 83-7-10$ & 11.2 \\
$83-4-69 \times 83-5-109$ & 9.1 \\
$83-4-69 \times 83-7-4$ & 11.9 \\
$83-4-69 \times 83-7-10$ & 10.6 \\
$83-5-109 \times 83-7-4$ & 11.4 \\
$83-5-109 \times 83-7-10$ & 12.5 \\
$83-7-4 \times 83-7-10$ & 14.3 \\
\hline
\end{tabular}

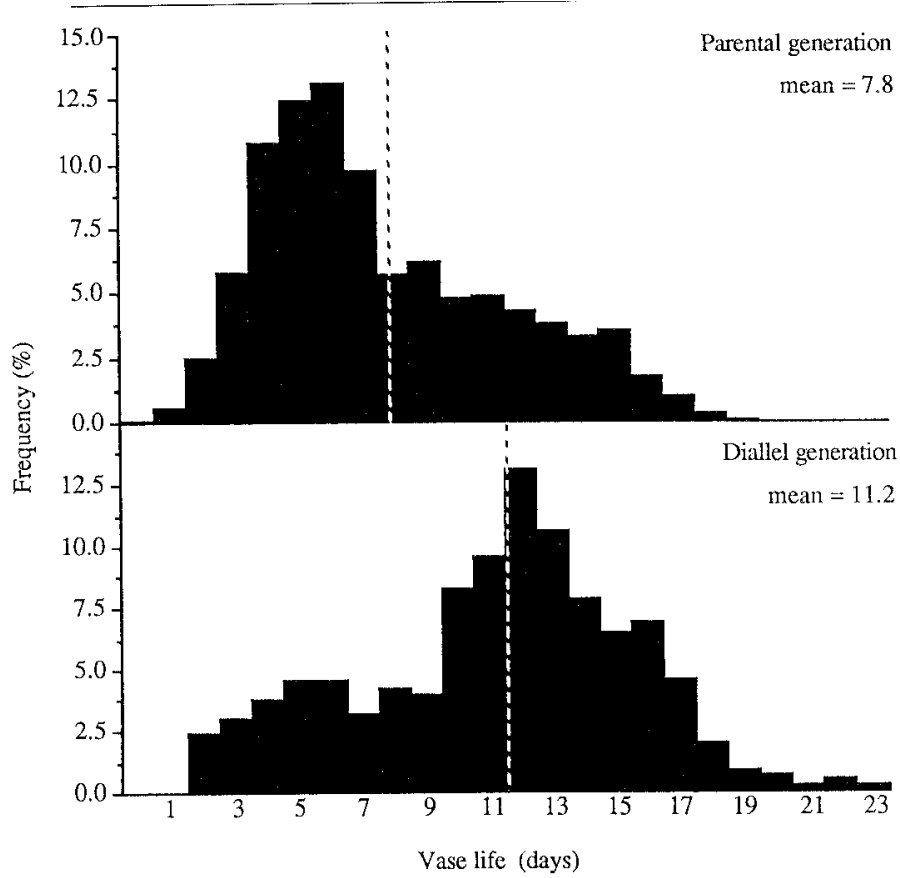

Fig. 1.Distribution of vase life dataon gerbera flowers from parental and diallel generations.

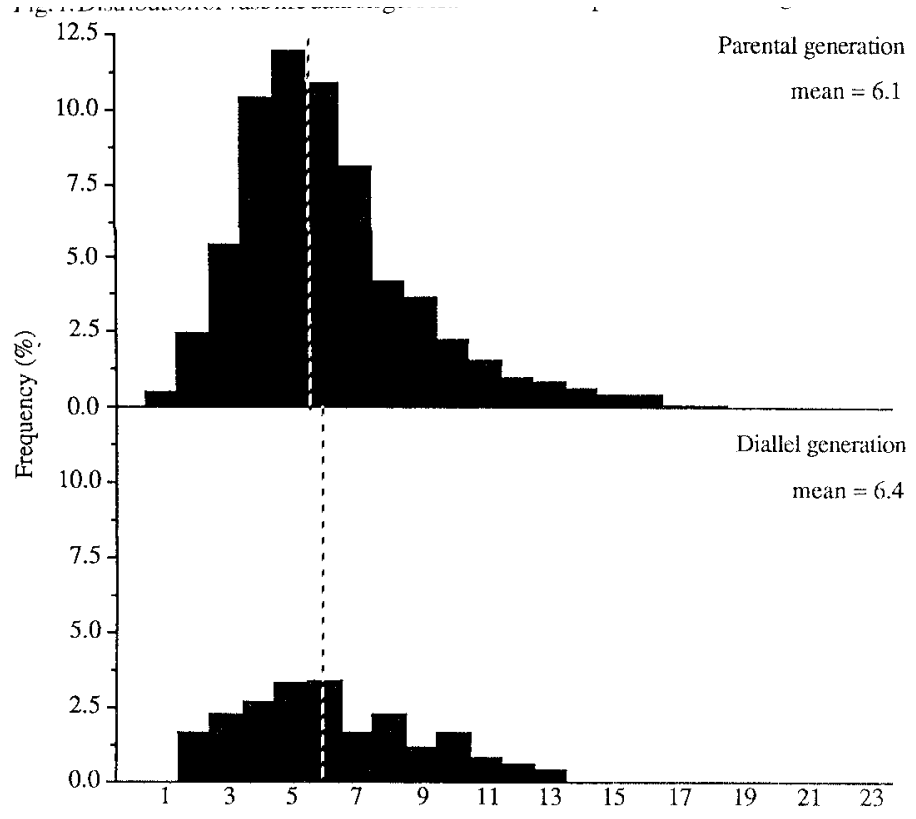

Vase life (days)

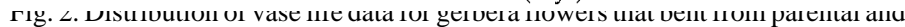
diallel generations.

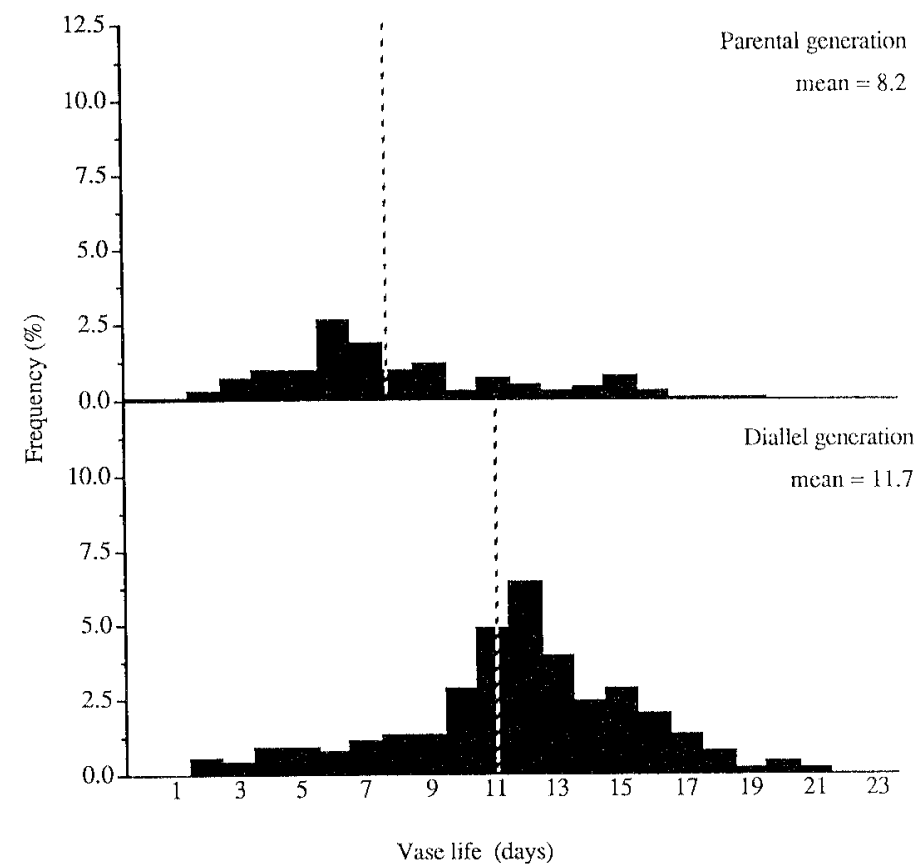

Fig. 3. Distribution of vase life data for gerbera flowers that folded from parental and diallel generations.

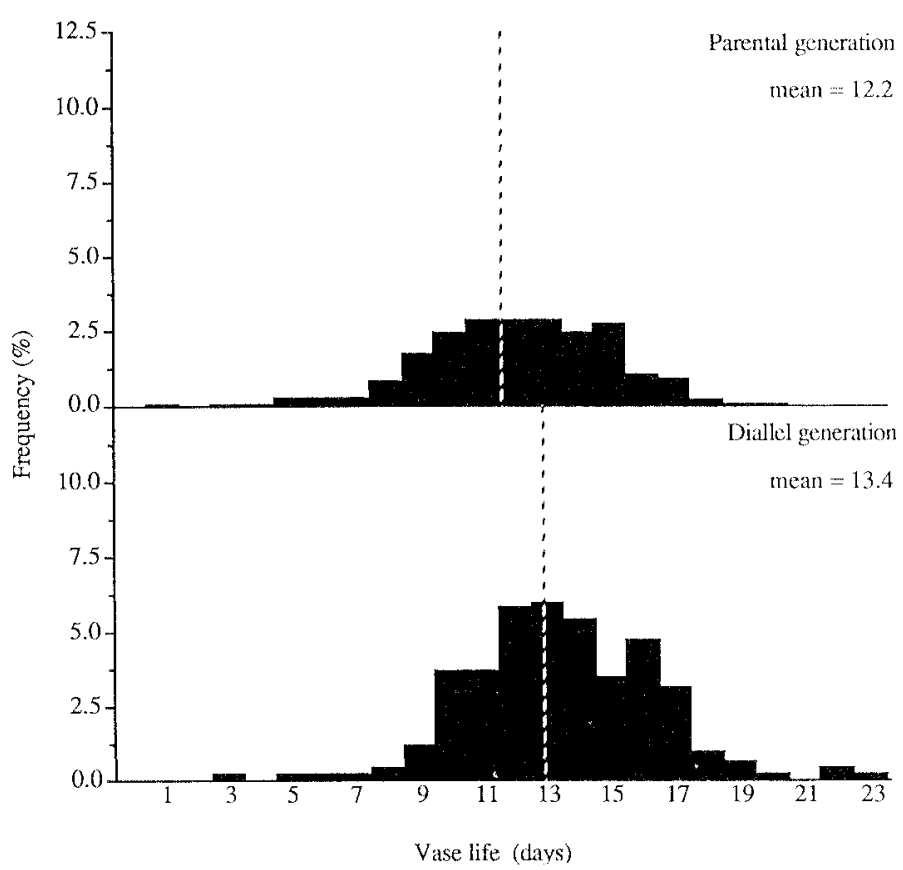

Fig. 4. Distribution of vase life data for gerbera flowers that wilted from parental and diallel generations.

Variation within plants or error MS for vase life was less when data were grouped by senescence modes than when an analysis of variance was made on vase life of all flowers. Differences in vase life of flowers among crosses were highly significant for all senescence modes. Differences among plants within crosses were also significant for days to folding and wilting, but nonsignificant for days to bending (Table 6).

\section{Discussion}

This study, which was based on a broad source of germplasm, has confirmed that vase life improvement in gerbera can be 


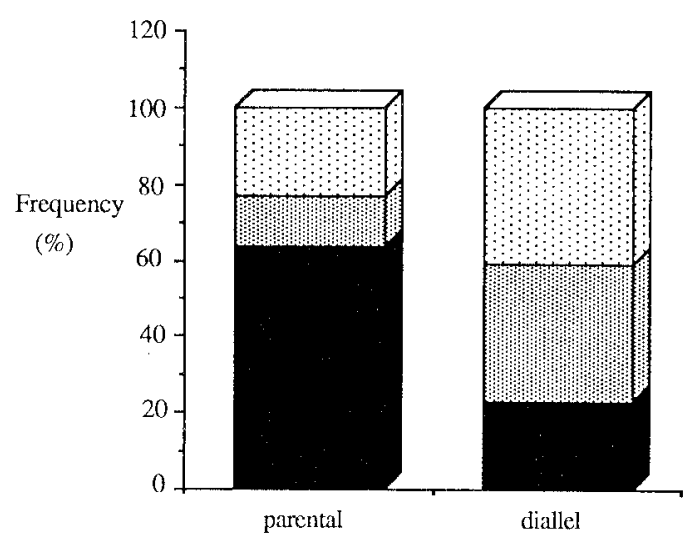

Generation

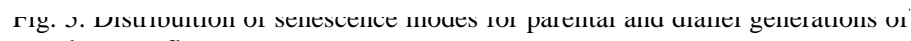
gerbera cut flowers.

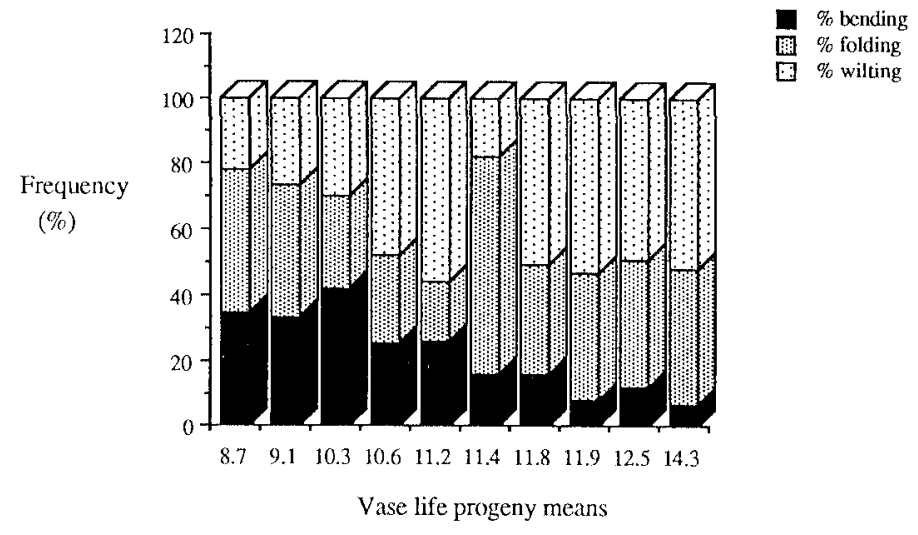

Fig. 6. Distribution of senescence mode frequency in progeny of diallel generation of gerbera cut flowers.

obtained by selecting and mating plants. Additional information was gained by classifying vase life determinations by three distinct modes of senescence; bending, folding, and wilting. The frequency of vase life days based on data from all flowers was not normally distributed before or after selection and mating. Yet, when frequency of vase life days was classified by senescence mode, distribution was normal. After selection and mating, increases in mean vase life for flowers that folded, bent, or wilted differed. For example, the increase in mean vase life for flowers that folded was much greater than that of flowers that bent or wilted. Combining this evidence, it is suggested that vase life may be a composite character of at least three components, represented by each senescence mode.

Further evidence to support this suggestion is found by comparing the magnitude of the error variance component $\left(\sigma^{2}\right)$ or error MS from an analysis of variance based on the total number of vase life observations vs. the error MS from individual analyses based on the number of vase life observations for each senescence mode. De Jong and Garretsen (1985) reported that if termination of vase life is not distinguished by stem collapse or ligulae wilt in an analysis of variance, a relatively large error variance would result. In fact, the error MS based on the total number of vase life observations from this data was nearly double the arithmetic mean of the error MS from individual analyses based on flowers that senesced due to bending, folding, and wilting (9.88 vs. 5.50).

This study was designed to evaluate the potential of improving postharvest longevity in gerbera by selecting plants with high vase life. Plants were not selected based on the specific number of days
Table 6. A $5 \times 5$ diallel. Analysis of variance for gerbera vase life (components).

\begin{tabular}{lrrr}
\hline \hline Source of variation & df & MS & F ratio \\
\hline \multicolumn{4}{c}{ All flowers } \\
Among crosses & 9 & 115.02 & $5.17^{* *}$ \\
Among plants & 238 & 22.26 & $2.25^{* *}$ \\
Within plants & 239 & 9.88 & \\
\multicolumn{5}{c}{ Days to bending } \\
Among crosses & 9 & 21.72 & $2.65^{* *}$ \\
Among plants & 70 & 8.24 & $1.36^{\text {NS }}$ \\
Within plants & 29 & 6.05 & \\
\multicolumn{5}{c}{ Days to folding } \\
Among crosses & 9 & 52.28 & $3.76^{* *}$ \\
Among plants & 124 & 14.42 & $3.16^{* *}$ \\
Within plants & 46 & 4.56 & \\
Among crosses & 9 & & $3.21^{* *}$ \\
Among plants & 120 & 8.77 & $1.49^{*}$ \\
Within plants & 68 & 5.88 & \\
\hline Ns,*,**,**** Significant or nonsignificant at $P \leq 0.050 .01$, or 0.001, respectively
\end{tabular}

to bending, folding, or wilting of their flowers. However, we find that selecting plants based on the number of days to bending, folding, or wilting, rather than the composite character of vase life. This may prove to be a useful approach to improving postharvest longevity in gerbera, since differences among crosses for vase life of flowers was determined to be highly significant for each senescence mode.

In support of conclusions previously presented (De Jong, 1986; De Jong and Garretsen, 1985), the specific incidence of bending, folding, or wilting, is proposed to be an important aspect of postharvest longevity in gerbera. Before selection and mating to improve vase life, a greater proportion of flowers senesced due to bending than wilting. Flowers that senesced due to bending generally exhibited lower vase life than flowers that senesced due to wilting. After selection and mating, a greater proportion of flowers senesced due to wilting than bending. The shift in proportion of these two modes that occurred was dramatic after only one generation of selection and mating. Therefore, it is postulated that the incidence of bending vs. wilting may be a qualitatively based trait controlled by relatively few genes.

In studies on breeding for maintaining quality in gerbera, De Jong (1986) distinguished senescence by three classes; early stem fold, late stem fold, and petal wilt. His definition for early stem fold was slightly different from that of bending in this study, but he reported that if selection were made against the phenomenon, its incidence could be reduced or eliminated fairly easily. He showed data for 59 progenies resulting from a diallel mating; four progenies did not exhibit early fold. After studying De Jong's results, it seems possible that the trait early fold vs. no early fold could fit a genetic model involving only two genes with epistatic effects $(15: 1)$. It seems plausible that a qualitative model may apply to the trait bending vs. wilting. Among ten progenies, bending was not completely eliminated, but in one case its incidence was reduced to only $5 \%$.

The incidence of stem folding may be distinct from the incidence of bending or wilting. Before selection and mating to improve vase life, the frequency of folding was relatively low. After selection and mating, the frequency of folding nearly tripled and vase life also increased. This created some speculation as to whether a higher proportion of folding is the result of longer lasting flowers. Yet when the proportion of folding for each progeny was 
compared to progeny means for vase life, this speculation could not be confirmed because some progeny with higher vase life showed a smaller proportion of folding than some progeny with lower vase life. Instead, the most striking observation of this comparison among ten progenies was that the proportion of folding could be grouped into four classes of about $20 \%, 30 \%$, $40 \%$, and $65 \%$. This causes us to wonder whether data from more progenies might yield a sufficient number of classes to identify a genetic model, which would indicate that folding is also qualitatively inherited. If so, it seems likely that the incidence of folding is controlled by at least several genes.

Breeding to improve vase life in gerbera has potential, although establishing lines with superior lasting quality may require recognizing vase life as a composite character. Breeding programs that incorporate selection against frequency of bending and folding, and selection for increased days to wilting, may be a more effective approach.

Breeding cultivars with superior postharvest longevity may be the best approach for satisfying the consumer's expectation of cut flower postharvest quality. Combining this effort with postharvest treatments, such as the use of floral preservatives, would help maintain the popularity of gerbera for years to come.

\section{Literature Cited}

Abdel-Kader, H. and M.N. Rogers. 1986. Postharvest treatment of Gerbera jamesonii. Acta Hort. 181:169-176.

Accati, E. G. 1989. Parameters influencing gerbera cut flower longevity. Acta Hort. 261:63-68.

Amariutei, A., I. Burzo, and C. Alexe. 1986. Researches concerning some metabolism aspects of cut gerbera flowers. Acta Hort. 181:331-337.

Burdett, A.N. 1970. The cause of bent neck in cut roses. J. Amer. Soc. Hort. Sci. 95:427-431.

Buys, C. 1978. Quality problems in gerbera, p. 255-262. In: L. Quagliotti and A. Baldi (eds.). Genetics and breeding of Carnation and Gerbera. Proc. Eucarpia Mtg., 24-28 Apr. Alassio, Italy.

De Jong, J. 1978a. Dry storage and subsequent recovery of cut gerbera flowers as an aid in selection for longevity. Scientia Hort. 9:389-397.

De Jong, J. 1978b. Selection for keeping quality in gerbera, p. 263-268. In: L. Quagliotti and A. Baldi (eds.). Genetics and breeding of carnation and gerbera. Proc. Eucarpia Mtg., 24-28 Apr., Alassio, Italy.

De Jong, J. 1986. Breeding for keeping quality in gerbera. Acta Hort. 181:353-357.
De Jong, J. and F. Garretsen. 1985. Genetic analysis of cut flower longevity in gerbera. Euphytica 34:779-784.

Harding, J., T.G. Byrne, and R.L. Nelson. 1981. Heritability of cut-flower vase longevity in gerbera. Euphytica 30:653-657.

Harding, J., T. Byrne, and D. Drennan. 1987. The use of a selection index to improve gerbera cut flowers. Acta Hort. 205:57-64.

Kohl, H.C. 1968. Gerberas: Their culture and commercial possibilities. S. Flor. Nursery 28:18,24-26.

Marousky, F.J. and S.S. Woltz. 1975. Relationship of floral preservatives to water movement, fluoride distribution, and injury in gladiolus and other cut flowers. Acta Hort. 41:171-182.

Nowak, J. 1981. Regulation of bud opening, storage period, vase-life and senescence of cut flowers. I. The effect of silver complexes and sucrose on longevity of cut gerbera inflorescences stored for different periods of time. Res. Inst. Pomol. Floricult. Annu. Rpt. 2:3-10.

Nowak, J. and H. Plich. 1981. Regulation of bud opening, storage period, vase-life, and senescence of cut flowers. II. The effect of silver ions and other anti-ethylene agents on ethylene synthesis and senescence of gerbera inflorescences. Res. Inst. Pomol. Floricult. Annu. Rpt. 2:10-21.

Serini, G. and V. De Leo. 1978. Phenotypic characters and preservability of gerbera flowers, p. 269-277. In: L. Quagliotti and A. Baldi (eds.). Genetics and breeding of carnation and gerbera. Proc. Eucarpia Mtg., 24-28 Apr., Alassio, Italy.

Smith, D.E. and R.L. Nelson. 1967. Gerbera propagation. Calif. Agr. 21(12):7.

Tesi, R. 1978. Variation of some characters of flowers in clones of Gerbera jamesonii hybrida, p. 227-232. In: L. Quagliotti and A. Baldi (eds.). Genetics and breeding of carnation and gerbera. Proc. Eucarpia Mtg., 24-28 Apr., Alassio, Italy.

van Meeteren, U. 1978a. Water relations and keeping quality of cut gerbera flowers. I. The cause of stem break. Scientia Hort. 8:65-74.

van Meeteren, U. 1978b. Water relations and keeping quality of cut gerbera flowers. II. Water balance of ageing flowers. Scientia Hort. 9:189-197.

van Meeteren, U. 1981. Role of pressure potential in keeping quality of cut gerbera inflorescences. Acta Hort. 113:143-150.

von Wilberg, B. 1973. Physiological investigations on the problem of freedom from stem break as a prerequisite in breeding gerbera forms which remain upright when used as cut flowers. Z. Pflanzenzuchtung 69:107-114.

Waters, W.E. 1964. Influence of chemical preservatives on keeping quality of asters, carnations, chrysanthemums, and gerbera daisies. Proc. Fla. State Hort. Soc. 77:466-470.

Zieslin, N., H.C. Kohl, A.M. Kofranek, and A.H. Halevy. 1978. Changes in the water status of cut roses and its relationship to bent-neck phenomenon. J. Amer. Soc. Hort. Sci. 103:176-179. 